\title{
PHLOEM NECROSIS IN THE STRIPE DISEASE OF CORN
}

By Merville T. Cook, Plant Pathologist, Agricultural Experıment Station, Río Piedras, P. R.

Phloem necrosis has been reported for a number of plants infected with virus diseases, especially potatoes, tomatoes and beets, and may oceur in many other plants infected with virus diseases. It is possible that it may be a diagnostic symptom in some types of virus diseases. However, this symptom must be studied in a much larger number of host planis and with a much larger number of viruses before its value in diagnosis and classification can be determined with certainty. We should also have a more complete knowledge of its appearance in plants with diseases due to other causes.

Gilbert (9) in a paper on correlation of foliage degeneration diseases of the Irish potato with variations of the tuber and sprout said-"Net-necrosis, of the phloem-necrosis type, is correlated in the tubers with a spindliness of sprout and seems to be a consistent symptom of leaf-roll. The necrosis symptoms are not persistent in the progeny tubers'. A few years later (10) he reported that he had demonstrations of direct relation between leaf-roll and net necrosis. Quanjer (12) who has probably made a more extensive study of phloem-necrosis than any other worker on this subject made an attempt to classify and name potato viruses on the basis of the necrosis characters. Various forms of necrosis produced by several viruses in several species of plants have been studied by many workers during the past quarter of a century. It is a fruifful field of research for both plant histology and plant physiology.

November 17th, 1934, the attention of the writer was called to an outbreak of a white stripe disease of corn growing in a garden on the Agricultural Experiment Station farm. The symptoms of the disease corresponded with the descriptions by Stahl in Cuba (13) and Britton Jones (1) in Trinidad.

Some of the plants were very much dwarfed and did not produce ears. Others were full sized, some of them producing ears and others barren. The tendency to sterility was very pronounced. So many of the plants were sterile that it was difficult to find an ear satisfactory for seed. A plant in which the symptoms were fairly 
good was selected and cross-polinated from a plant in which symptoms were very pronounced. Chlorosis of the upper leaves was characteristic in all cases and the pattern was that of stripes which followed the veins of the leaves. In some cases a single white vein ran through a dense green leaf. In other cases the leaf was almost white.

Four plants were selected and pieces of the leaves fixed for sectioning. These pieces were sectioned and stained for study.

Phloem necrosis was found in every case ranging from a very slight to a very pronounced necrosis (figures 1 to 5 ). In some few cases a similar condition was found in the parenchyma (figures 7 , $8,9,10,11)$. In the most severe cases there was a complete breakdown (figure 6) of many cells. In some cases there was an increase in the number of fibrous cells next to the epidermis and a thickening of the walls of these cells. The phloem necrosis was acompanied by a thickening of the walls of the epidermis cells, the fibrous cells and sheath (figures 1 to 5 and 12, 13). In some cases these cells developed thick walls, although there was no phloem necrosis (figure 12). Esau (1934) in a paper on curly-top of sugar beet reported "a collapsed parenchyma that had undergone degeneration and necrosis".

In the most extreme cases the part of the leaf in which the stripe was located was very thin (figure 12), but this was not necessarily accompanied by phloem-necrosis.

The effect on the cell contents was very noticeable. The chloroplasts in the sheath cells of the bundles with necrosis and the parenchyma cells around such bundles were few in number (figure 14) while the corresponding cells in a section from a healthy plant showed a large number of chloroplasts (figures 15, 16). The chloroplasts in the cells in healthy plants where somewhat larger in size than those in cells from chlorotic regions of diseased plants. There was no evidence of disintegration but abundant evidence of inhibition. This is in harmony with the work of the writer on mosaic diseases of sugar cane and other plants $(3,4,5)$. In this connection it should be noted that Esau reported disintegration in two papers on curly top of sugar beet $(6,7)$.

The nuclei in severely infeeted regions showed evidence of disintegration. Esau (7) reported hypertrophy of the nuclei in sugar beets infected with curly top.

Intracellular bodies were not seen. 


\section{LITERATURE}

1. Britton-Jones, H. R. Stripes disease of corn (Zea mays L) in Trinidad. Tropical Agriculture (Trinidad) 10(5):119-122. 1923.

2. Carsner, E. \& Stahl, C. F. Studies on curly-top disease of sugar beet. Journ, Agri. Res. 28: 297-320. 1924.

3. Cook, Melville T. Histology and Cytology of sugar cane mosaic. 9(1)5-27. 1925.

4.

The effect of mosaic on the content of the plant cell. 9 (3 \& 4):229-238. 1926.

5. and chloroplasts. 15(2):177-181. 1931.

6. Esau, Katherine. Pathologic changes in the anatomy of leaves of the sugar beet, Beta vulgaris L. affected by curly-top. Phytopathology 23(9): 679-712. 1933.

7. - Cell degeneration in relation to sieve-tube differentiation in curly-top beets. A preliminary note. Phyto. 24(3) : 303-305. 1934.

8. Gardner, W. IMI. Necrosis, hyperplasia, and adhesions in mosaic I ..... tomato fruits. Journ. Agri. Res. 30:871-888. 1925.

9. Gilbert, A. H. Correlation of foliage degeneration diseases of the Irish potato with variations of the tuber and sprout. Journ. Agri. Res. 25:255-266. 1923.

10.

Production of potato tuber necrosis. Science 67:464-465. 1928.

11. - Net-necrosis of Irish potato tubers. Vermont Agric. Exp. Station Bulletin 289. 1928.

12. Quanjer, H. II. The Methods of classification of plant viruses and an attempt to classify and name potato viruses. Phyto. $21: 577-613.1931$.

13. Stahl, C. F. Corn stripe disease in Cuba not identical with sugar cane mosaic. Tropical Plant Research Foundation Bul.etin $7: 3-11.1927$.

14. Smith, R. E. \& Boncquet, A. New light on curly top of the sugar beet. Phyto. 5:103-107. 1915.

\section{Explanation of Plates}

Figure 1.-Cross section of a leaf showing necrosis just above the lower epidermis.

Figure 2.-Cross section of leaf showing very slight necrosis.

Figure 3.-Another section showing same condition, but more pronounced.

Figure 4.-A section showing same conditions accompanied by a pronounced thickening of the epidermis.

Figure 5. A section showing necrosis and thickening of walls in the epidermis. 
Figure 6.-A severe case in which there is a breaking down of cells in the fibro-vascular bundle.

Figure 7.-Necrosis and thickening cell walls in the parenchyma.

Figure 8.-Necrosis in the parenchyma adjacent to the sheath cells of the fibro-vascular bundle.

Figure 9.-A more pronounced case of necrosis in the parenchyma. cells.

Figure 10.-A very pronounced case of necrosis next to the epidermis.

Figure 11.-A very pronounced necrosis surrounding a very small fibro-vascular bundle.

Figure 12.-A very pronounced thickening of cells of the epidermis. Note that the leaf is very thin in one place.

Figure 13.-Thickening of the walls of the epidermis and adjoining cells. Also the walls of the sheath cells surrounding a fibrovascular bundle.

Figure 14.-Sheath cells and adjoining cells of a severely infected. plant. Note that the chloroplasts are very few and very small.

Figure 15.-The same from a slightly infected plant.

Figure 16.-The same from a healthy plant. 


\section{Plate I}

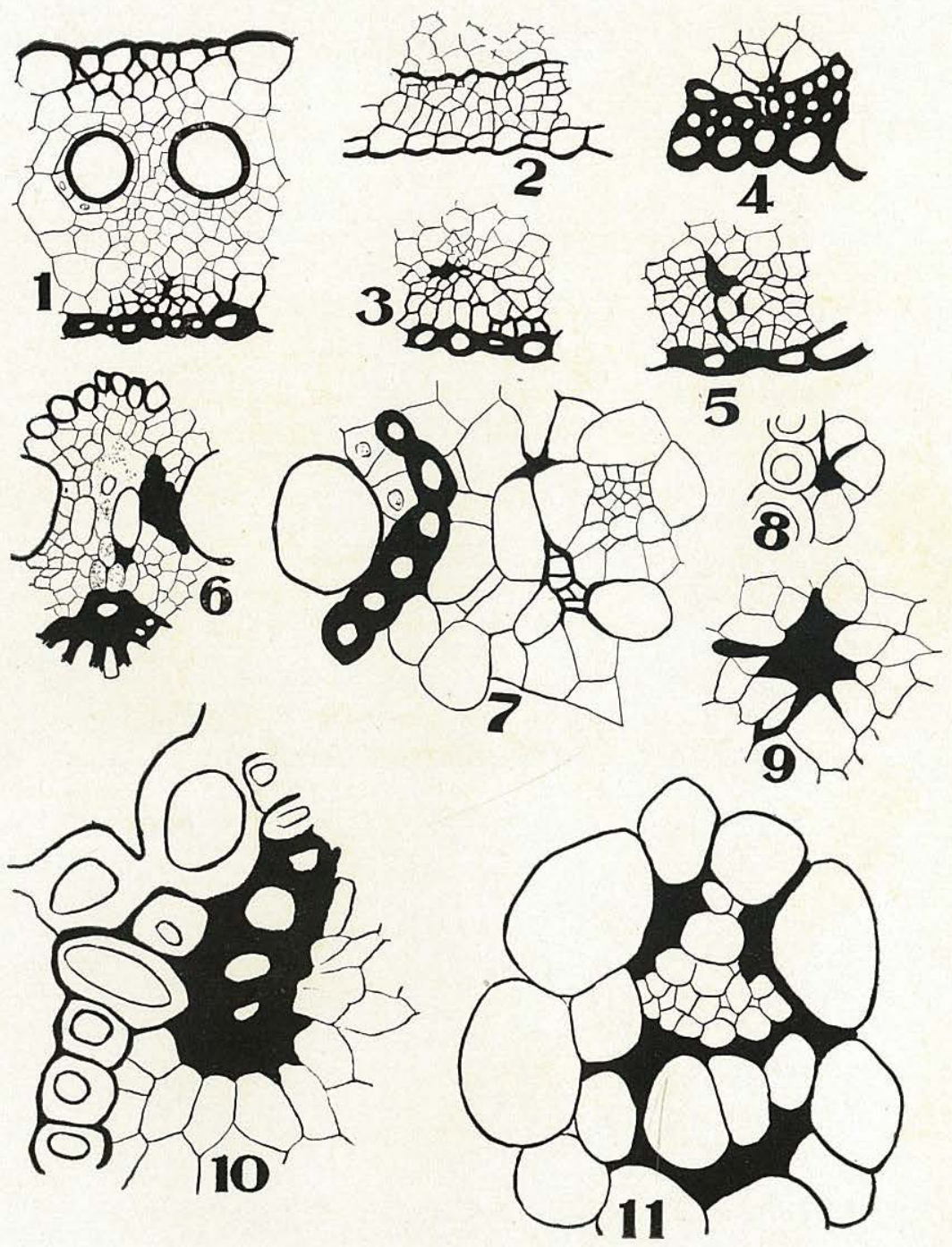




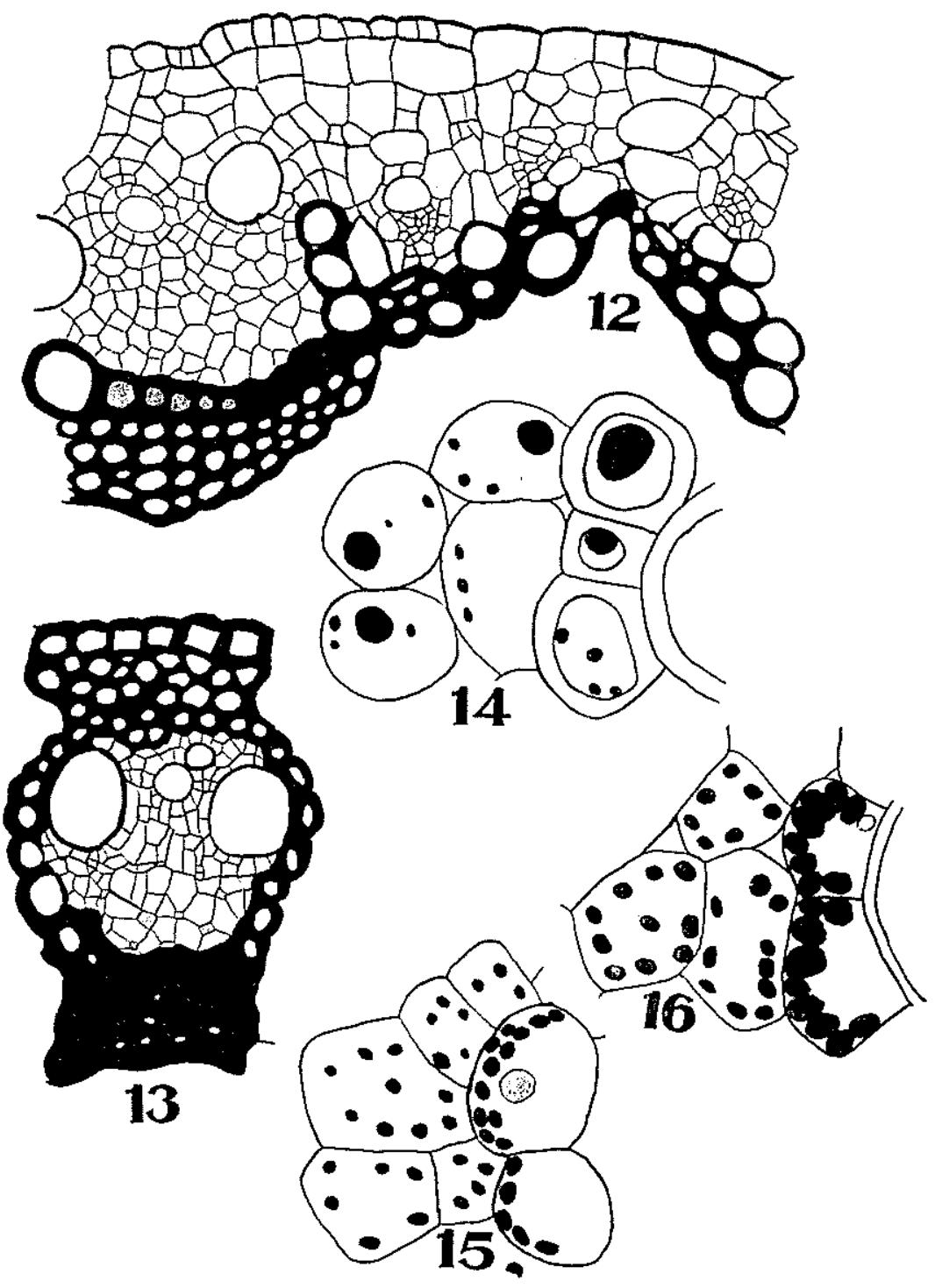

